\title{
Quantification of the chemokines CCL17 and CCL22 in human colorectal adenocarcinomas
}

\author{
DICK WÅGSÄTER ${ }^{1}$, OLAF DIENUS ${ }^{2}$, STURE LÖFGREN ${ }^{2}$, ANDERS HUGANDER $^{3}$ and JAN DIMBERG ${ }^{4}$ \\ ${ }^{1}$ Atherosclerosis Research Unit, Center for Molecular Medicine, Department of Medicine, Karolinska Institute, Stockholm; \\ Departments of ${ }^{2}$ Clinical Microbiology, and ${ }^{3}$ Surgery, Ryhov County Hospital, Jönköping; ${ }^{4}$ Department of \\ Natural Science and Biomedicine, University College of Health Sciences, Jönköping, Sweden
}

Received November 12, 2007; Accepted December 20, 2007

\begin{abstract}
Chemokines are believed to play a crucial role in local immunoresponse by regulating leukocyte movement in various tissues, including the intestinal mucosa. It has been suggested that they are key players in cancer biology, and several studies have identified leukocyte infiltration as a hallmark of most cancers. The chemokines CCL17 and CCL22 attract CCR4-bearing cells, which are especially polarised to Th2-type cells and regulatory $\mathrm{T}$ cells (Treg). Recent studies have revealed the participation of the CCL17 and CCL22 proteins in diseases such as atopic dermatitis and lymphoma. The purpose of this study was to assess the role of CCL17 and CCL22 protein expression in colorectal cancer (CRC) and to ascertain whether an association exists between promoter 431C > T CCL17 and -961G>A CCL22 gene polymorphisms in CRC versus non-CRC subjects. Using the ELISA assay, we noted a significantly higher expression of CCL22 in tumour tissue with a 2.3-fold up-regulation (tumour vs. paired normal tissue, $n=78$ ) but no significant difference in CCL17 protein expression. Immunohistochemistry revealed protein expression of CCL22 and CCL17 in the epithelial compartment of cancer tissue, in epithelial cells at the resection border that reflects normal tissue, and in some stromal cells such as lymphocytes, macrophages, and fibroblasts. Using a TaqMan system we screened for $-431 \mathrm{C}>\mathrm{T}$ CCL17 and $-961 \mathrm{G}>\mathrm{A}$ CCL22 gene variants in 245 CRC patients and 256 controls, but could not find any significant difference in genotype distribution or in allelic frequencies between the two groups. The genotype and allelic distributions of CRC patients were not related to tissue levels of CCL17 and CCL22 protein, and none of the variables were associated with plasma levels or clinical characteristics. To ascertain whether the tissue expression of CCL17 and
\end{abstract}

Correspondence to: Dr Jan Dimberg, Department of Natural Science and Biomedicine, University College of Health Sciences, Box 1026, SE-551 11 Jönköping, Sweden

E-mail: jan.dimberg@hhj.hj.se

Key words: CCL17, CCL22, polymorphism, protein expression, colorectal cancer
CCL22 exerts an influence on the pathogenesis of CRC, a forthcoming study on the 5-year survival rate of CRC patients will be conducted.

\section{Introduction}

Chemokines are chemotactic cytokines that participate in the migration of various types of inflammatory cells and play an important role in the local immunoregulation of various tissues, including the intestinal mucosa (1-3). In general, chemokines are thought to be key players in cancer biology (4). Studies have demonstrated that leukocyte infiltration is a hallmark of most cancers (5-7) and promotes and regulates tumour growth, including metastasis and angiogenesis $(8,9)$. T cell infiltration has been shown to be associated with a favourable prognosis in colorectal cancer (CRC) $(10,11)$.

The chemokines CCL17 and CCL22 have been the subject of immunogene therapy studies in murine models of colon carcinoma (12). The chemokine CCL17, also referred to as TARC (thymus- and activation-regulated chemokine), is a member of the $\mathrm{CC}$ chemokine group that is expressed in the thymus, dendritic cells, endothelial cells, colon tissue, keratinocytes and fibroblasts (13-17). Moreover, CCL17 is a ligand for $\mathrm{CC}$ chemokine receptor 4 (CCR4) and attracts CCR $4{ }^{+}$cells $(18,19)$. It has been suggested that CCR4 is especially polarised to Th2-type cells (19-21) and that these cells produce anti-inflammatory cytokines such as IL-4, IL-5, IL-10 and IL-13 (20,21). CCR4 is also expressed on regulatory $\mathrm{T}$ cells (Treg), which play an important role in maintaining immune balance and have been detected in peripheral blood from humans $(22,23)$.

Another ligand for CCR4 is CCL22, also named MDC (macrophage-derived chemokine), which is expressed in macrophages, dendritic cells, B cells, intestinal epithelial cells and colon tissue, and thereby serves to recruit CCR4expressing cells $(16,18,19,24,25)$. A study has shown that CCL22, but not CCL17, mRNA was elevated in colon cancer tissues compared to non-neoplastic colon tissues, and that CCR4 transcripts were weakly detected in some colon cancer tissues (26).

A single nucleotide polymorphism (SNP) of the CCL17 gene, located in the promoter region as a $\mathrm{C} \rightarrow \mathrm{T}$ change at position -431 (rs223828), has been reported (27). This SNP has been shown to enhance the promoter activity of the CCL17 
gene, and individuals carrying the $-431 \mathrm{~T}$ allele showed significantly increased serum levels of CCL17 compared to those not carrying it $(28,29)$. The SNPs of the CCL22 gene have been identified and one of them, $-961 \mathrm{G}>\mathrm{A}$ (rs223888), is located in the 5'-flanking region (27). However, its functional significance is as yet unknown. Both CCL17 and CCL22 are members of the chemokine gene cluster (CCL22, CX3CL1, CCL17) located on chromosome 16 (27).

Based on the documented importance of chemokines as important actors in cancer biology and the maintenance of normal local immunity, we performed an investigation of CCL17 and CCL22 protein expression in CRC patients. Moreover, we investigated the influence of the CCL17 and CCL22 gene variants on CRC.

\section{Materials and methods}

Patients and controls. Blood samples were obtained from 245 patients from southeastern Sweden who underwent surgical resections for primary colorectal adenocarcinomas at the Department of Surgery, Ryhov County Hospital, Jönköping, Sweden. This patient group comprised 124 males and 121 females with a mean age of 70 years (range 29-93). The tumours were localised in the colon $(n=123)$ and rectum $(n=122)$ and were classified according to Dukes' classification system: stage A $(n=47)$, stage $B(n=102)$, stage $C(n=82)$ and stage D $(n=14)$. Blood donors $(n=256)$ from Ryhov County Hospital with no known CRC history and from the same geographical region as the $\mathrm{CRC}$ patients were selected as the controls. This control group consisted of 136 males and 120 females with a mean age of 67 years (range 50-93).

Plasma samples. Of the CRC patients, 71 were available for plasma collection. Patient blood was collected before surgery and all blood - including samples from 101 controls - was separated by centrifugation within $1 \mathrm{~h}$. Plasma was removed and stored at $-70^{\circ} \mathrm{C}$. The CRC patient group comprised 39 males and 32 females with a mean age of 69 years (range 29-88). The patient tumours were categorised according to Dukes' classification: stage A $(n=16)$, stage B $(n=29)$, stage C $(n=24)$ and stage $D(n=2)$. Thirty-six tumours were located in the rectum and 35 in the colon.

Tissue samples and lysates. Tissue samples available from the CRC patients were used. The tumours and matched normal mucosa used for CCL17 analysis included 42 males and 36 females and were classified according to Dukes' classification system: stage A $(n=17)$, stage $B(n=31)$, stage $C(n=27)$ and stage $D(n=3)$. The tumours were localised in the colon $(n=38)$ and rectum $(\mathrm{n}=40)$. The tumours and matched normal mucosa used for CCL22 analysis included 40 males and 38 females and were classified according to Dukes' classification system: stage A $(n=15)$, stage $B(n=29)$, stage $C(n=26)$ and stage $D$ $(n=8)$. The tumours were localised in the colon $(n=38)$ and rectum $(n=40)$.

Tumour tissue and adjacent normal mucosa $(\sim 5 \mathrm{~cm}$ from the tumour) from each patient were excised and immediately frozen at $-70^{\circ} \mathrm{C}$ until analysis.

Frozen tumour tissue and normal mucosa were thawed, homogenised in ice-cold lysis buffer containing PBS (9.1 mM dibasic sodium phosphate, $1.7 \mathrm{mM}$ monobasic sodium phosphate, $150 \mathrm{mM} \mathrm{NaCl}, \mathrm{pH} 7.4$ ) and $1 \%$ Nonidet P-40, $0.5 \%$ sodium deoxycholate, $0.1 \%$ sodium dodecyl sulphate (SDS), $100 \mu \mathrm{g} / \mathrm{ml}$ phenylmethylsulphonyl flouride (PMSF), $2 \mu \mathrm{g} / \mathrm{ml}$ aprotinin, $1 \mathrm{mM}$ sodium orthovanadate and $1 \mu \mathrm{g} / \mathrm{ml}$ leupeptin. The lysate was placed on ice for $30 \mathrm{~min}$ and then centrifuged at $13,000 \mathrm{x} \mathrm{g}$ for $10 \mathrm{~min}$. The protein content of the supernatant fluid was determined for each sample using the Bradford protein assay (Bio-Rad Laboratories, UK).

CCL17 and CCL22 by ELISA. CCL17 and CCL22 were measured in plasma and tissue using an established commercially available enzyme-linked immunosorbent (ELISA) Kit (R\&D Systems Europe, UK) following the manufacturer's instructions. The plasma CCL17 and CCL22 levels of CRC patients were expressed as picograms per millilitre $(\mathrm{pg} / \mathrm{ml})$, and the tissue levels of CCL17 and CCL22 from the tumour and paired normal tissue were expressed as picograms per milligram $(\mathrm{pg} / \mathrm{mg})$ of protein.

Immunohistochemistry. Twelve tumour samples were available for immunohistochemical staining to study the cell type origin of CCL17 and CCL22 expression. Staining was performed using a standard protocol on $4-\mu \mathrm{m}$ sections from formalinfixed paraffin-embedded tissue blocks. Endogenous peroxidase activity was quenched by treatment with $3 \%$ hydrogen peroxide for $5 \mathrm{~min}$. Sections were subsequently incubated with a primary goat anti-human monoclonal CCL17 antibody (R\&D Systems Europe) and with a primary rabbit anti-human polyclonal CCL22 antibody (PeproTech, NJ, USA) at the appropriate dilution for $4 \mathrm{~h}$ at room temperature. After rinsing in Tris-buffered saline, sections were incubated with a secondary biotin0ylated antibody; horse anti-goat IgG (Immunkemi, Sweden) for CCL17 and goat anti-rabbit IgG (Immunkemi) for CCL22. Avidin-biotin peroxidase complexes (Dako Cytomation, Denmark) were added followed by visualization with 3,3'-diaminobenzidine tetrahydrochloride (Dako Cytomation). All sections were counterstained with Mayer's hematoxylin (Histolab Products AB, Sweden). As negative controls, the primary antibodies were replaced by an isotype control $\mathrm{IgG}$.

Genotyping of the CCL17 and CCL22 polymorphisms. All blood was stored frozen until DNA was extracted using the QiaAmp DNA Blood Kit (Qiagen, CA, USA). DNA samples were genotyped using the 5'-exonuclease allelic discrimination assay (Applied Biosystems, CA, USA). TaqMan SNP Genotyping assays were used for analysis of the rs 223828 (CCL17) and rs223888 (CCL22) genotype, respectively (Applied Biosystems). DNA (10 ng) was amplified in a total volume of $12 \mu 1$ containing $1 \mathrm{X}$ TaqMan Universal PCR Master Mix (Applied Biosystems) including 1X TaqMan SNP Genotyping assay. Amplification was performed by an initial cycle of $50^{\circ} \mathrm{C}$ for $2 \mathrm{~min}$ then $95^{\circ} \mathrm{C}$ for $10 \mathrm{~min}$, followed by 40 cycles at $95^{\circ} \mathrm{C}$ for $15 \mathrm{sec}$ and $60^{\circ} \mathrm{C}$ for $1 \mathrm{~min}$. A post-PCR endpoint plate reading was performed on each plate using the 7500 Fast Real-Time PCR System (Applied Biosystems). The manual calling option in the allelic discrimination application ABI PRISM 7500 SDS software version 1.3.1 was then used to assign genotypes. 
A

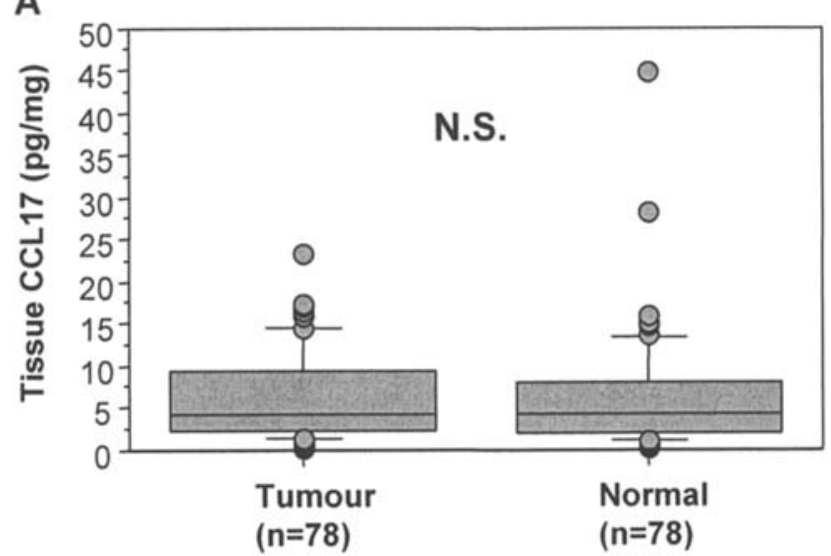

B

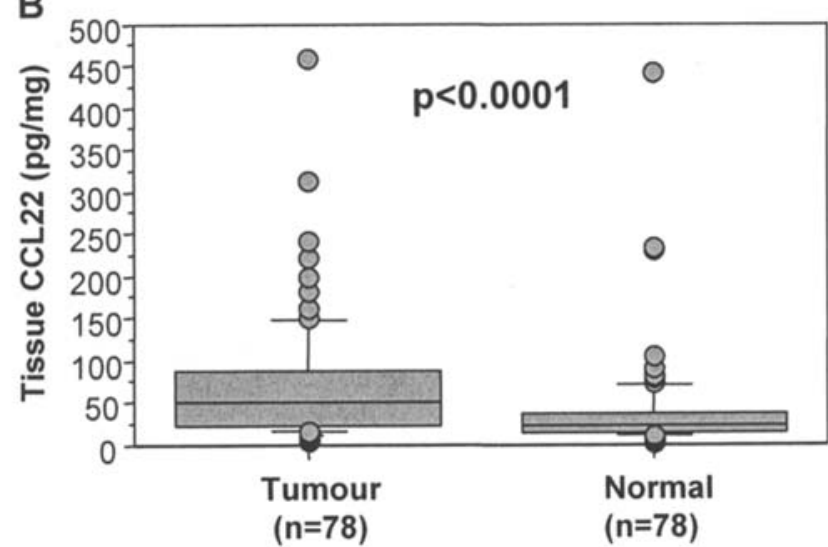

Figure 1. Protein levels of CCL17 and CCL22 in colorectal tissue. The protein expression levels of CCL17 (A) and CCL22 (B) were measured by ELISA in 78 biopsies from colorectal cancerous tissues and paired normal tissue from CRC patients. N.S., not significant.

Statistical analysis. Differences in the frequencies of the CCL17 and CCL22 polymorphisms between CRC patients and the control group and between clinical data within the CRC subgroup were analysed using the $\chi^{2}$ test, and the HardyWeinberg equilibrium was tested for all polymorphisms. Differences in the CCL17 and CCL22 protein expression of tumour and normal paired tissues were examined by the Wilcoxon signed rank test, and correlation coefficients were determined using the Spearman's rank correlation test. Statistical analysis was performed using the SPSS for Windows computer package (rel. 14.0, 2005; SPSS Inc., Chicago, IL, USA). Results were considered significant at $\mathrm{p}<0.05$.

\section{Results}

Levels of CCL17 and CCL22 in colorectal tissue and plasma. In order to investigate the potential role played by CCL17 and CCL22 as tumour markers, we measured the concentrations of the two in the plasma and protein lysates of colorectal cancerous tissues and matched normal tissues from 78 CRC patients using ELISA. No difference was seen in the levels of CCL17 protein in cancer tissue (median $4.2 \mathrm{pg} / \mathrm{mg}$; range $0.3-23.5 \mathrm{pg} / \mathrm{mg}$ ) in comparison with paired normal tissue (median $4.2 \mathrm{pg} / \mathrm{mg}$; range 0.1-44.8 pg/mg) (Fig. 1). However,
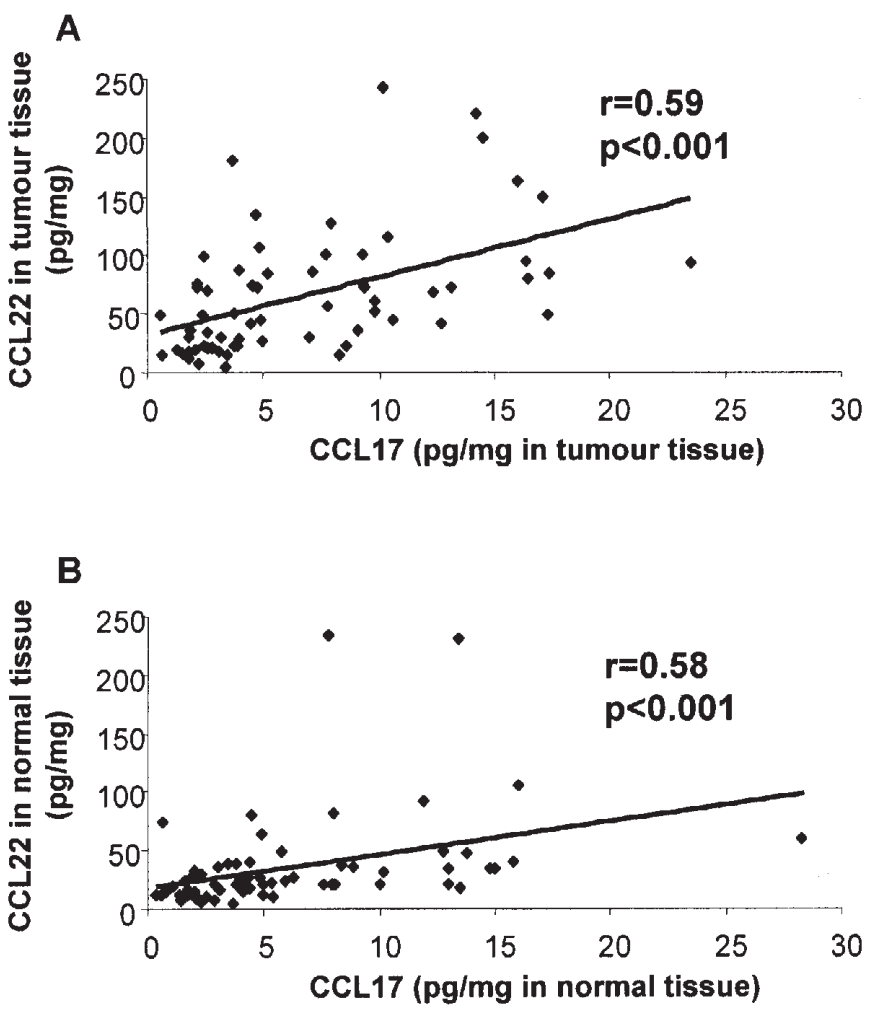

Figure 2. Correlation between protein levels of CCL17 and CCL22 in cancerous tissue (A) and normal tissue (B).

the levels of CCL22 protein in cancer tissue (median $49.6 \mathrm{pg} / \mathrm{mg}$; range $4.1-461 \mathrm{pg} / \mathrm{mg}$ ) showed a significant $(\mathrm{p}<0.0001) 2.3$-fold up-regulation in comparison with paired normal tissue (median $21.2 \mathrm{pg} / \mathrm{mg}$; range $2.6-461 \mathrm{pg} / \mathrm{mg}$ ) (Fig. 1). Assessing the relative expression (tumour vs. normal tissue) showed that $82 \%(64 / 78)$ of the cases were upregulated. Tissues from 66 of the CRC patients were available for determination and comparison of both CCL17 and CCL22 protein levels, respectively. We noted that the protein levels of CCL17 and CCL22 in cancerous tissue were significantly correlated $(r=0.59, p<0.001)$. The same was observed in normal tissue $(r=0.58, p<0.001)$ (Fig. 2). Plasma levels of CCL17 and CCL22 were lower in CRC patients than in control subjects (data not shown). Levels of CCL17 and CCL22 protein in all the analysed tissue samples from CRC patients were not associated with plasma levels or clinical characteristics such as gender, location and Dukes' stage, nor were the plasma levels of CCL17 and CCL22 protein (data not shown).

Immunohistochemical findings. Immunohistochemistry was performed in order to detect the location of CCL17 and CCL22 protein expression. Heterogenous immunoreactivity was evident mainly in the epithelial compartment of cancer tissue and in epithelial cells at the resection border that reflects normal tissue (Fig. 3). We also detected immunoreactivity localised in some stromal cells with the morphological characteristics of lymphocytes, macrophages, fibroblasts and, probably, dendritic cells. No staining was observed when an isotypic IgG antibody was used as a negative control. 

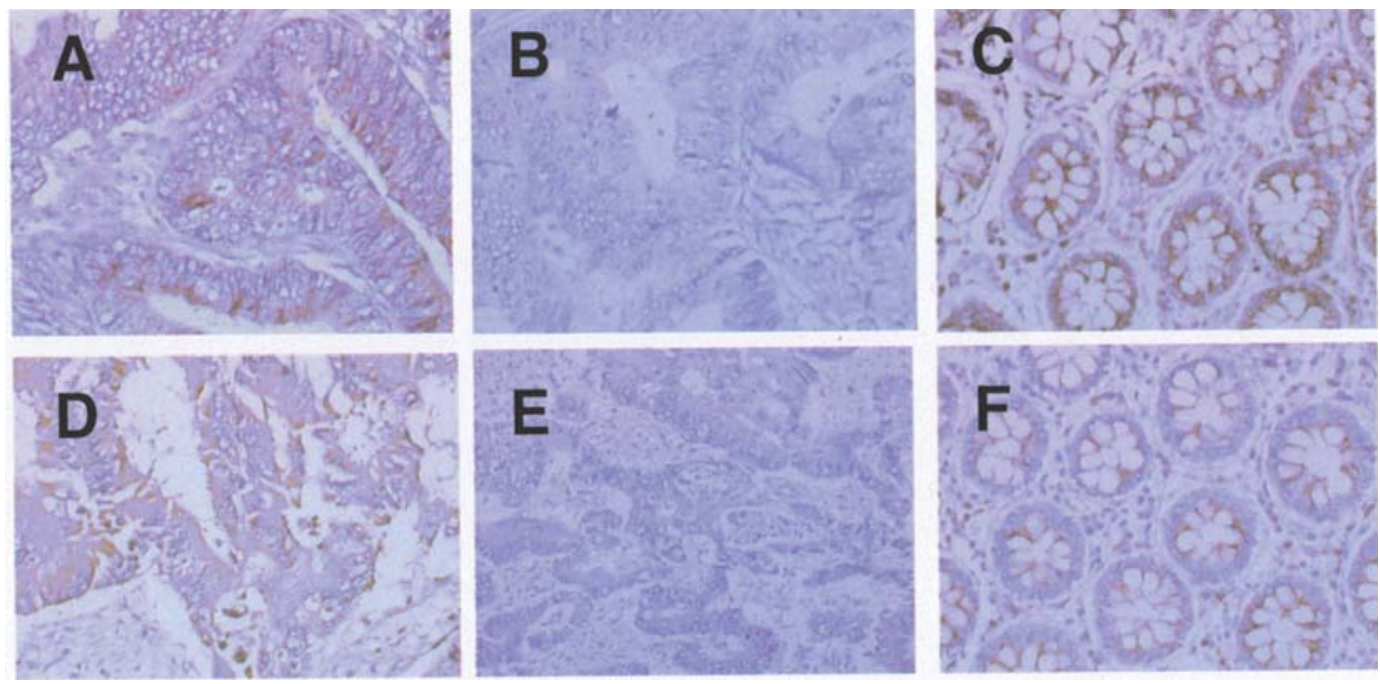

Figure 3. Immunohistochemical detection and localization of CCL17 and CCL22 in colorectal tissue from patients with colorectal cancer. Detection of CCL17 in cancerous tissue (A) and normal tissue (C) and CCL22 in cancerous tissue (D) and normal tissue (F). Isotypic IgG served as a negative control for the corresponding CCL17 (B) and CCL22 (E) in cancerous tissue; magnification, x200.

Table I. Genotypes and allele frequencies expressed as \% (n) of the single nucleotide polymorphisms of CCL17 and CCL22 genes in CRC patients and controls.

\begin{tabular}{|c|c|c|c|c|c|}
\hline Genotype & $\begin{array}{c}\text { CRC } \\
(n=245)\end{array}$ & $\begin{array}{l}\text { Control } \\
(\mathrm{n}=256)\end{array}$ & Allele & $\begin{array}{c}\text { CRC } \\
(n=490 \text { alleles })\end{array}$ & $\begin{array}{c}\text { Control } \\
(\mathrm{n}=512 \text { alleles })\end{array}$ \\
\hline \multicolumn{6}{|c|}{ CCL17 $(-431 \mathrm{C}>\mathrm{T})$} \\
\hline $\mathrm{C} / \mathrm{C}$ & 86.5 (212) & 87.9 (225) & $\mathrm{C}$ & $93.3(457)$ & $93.6(479)$ \\
\hline $\mathrm{C} / \mathrm{T}$ & $13.5 \quad(33)$ & $11.3 \quad(29)$ & $\mathrm{T}$ & $6.7 \quad(33)$ & $6.4 \quad(33)$ \\
\hline $\mathrm{T} / \mathrm{T}$ & $\begin{array}{ll}0 & (0)\end{array}$ & $0.8 \quad(2)$ & & & \\
\hline \multicolumn{6}{|c|}{ CCL22 (-961G>A) } \\
\hline $\mathrm{G} / \mathrm{G}$ & $53.9(132)$ & $61.7(158)$ & G & $74.7(366)$ & $77.5(397)$ \\
\hline G/A & $41.6(102)$ & $31.6(81)$ & A & $25.3(124)$ & $22.5(115)$ \\
\hline $\mathrm{A} / \mathrm{A}$ & $4.5 \quad(11)$ & 6.7 & & & \\
\hline
\end{tabular}

CRC patients versus controls: CCL17 genotypes, overall p=0.301; CCL17 alleles, $\mathrm{p}=0.854$; CCL22 genotypes, overall $\mathrm{p}=0.055$; CCL22 alleles, $\mathrm{p}=0.291$.

CCL17 and CCL22 polymorphism. To analyse whether an association exists for promoter $-431 \mathrm{C}>\mathrm{T}$ CCL17 and $-961 \mathrm{G}>\mathrm{A}$ CCL22 gene polymorphisms between CRC patients and controls, we used a TaqMan allelic discrimination system. There was no significant difference in genotype distribution or in allelic frequencies between CRC patients and control subjects (Table I). However, there was a trend $(\mathrm{p}=0.055)$ towards deviation in CCL22 genotype distribution between CRC patients and controls. Furthermore, we found seven combined genotypes, but no significant difference in combined genotype distribution between CRC patients and control subjects (Table II).

Genotype and allelic distributions in CRC patients were not associated with clinical characteristics such as location, Dukes' stage (Table III), gender, plasma or the tissue levels of CCL17 and CCL22 (data not shown). All genotype distributions were in Hardy-Weinberg equilibrium.

\section{Discussion}

Chemokines play an important role in local immunoregulation by regulating leukocyte movement in different tissues, including the intestinal mucosa (1-3). Chemokines are thought to be key players in cancer biology (4), and studies have demonstrated that leukocyte infiltration is an important characteristic of most cancers (5-7) that promotes and regulates tumour growth, including metastasis and angiogenesis $(8,9)$.

The chemokines CCL17 and CCL22 attract CCR4-bearing cells, in particular Th2-type cells (19-21) and regulatory Tregs $(22,23)$. Recent studies have revealed the participation of the CCL17 and CCL22 proteins in diseases such as atopic dermatitis (30) and lymphoma (31). It has been reported that mRNA expression of CCL17 and CCL22 may have an impact on CRC (26). 
Table II. Distribution of combined genotypes expressed as \% (n) of the -431C>T CCL17 and -961G>A CCL22 gene polymorphisms in CRC patients and controls.

\begin{tabular}{|c|c|c|c|c|}
\hline $\begin{array}{l}\text { Combined } \\
\text { genotype }\end{array}$ & $\begin{array}{c}-431 \mathrm{C}>\mathrm{T} \\
\mathrm{CCL} 17\end{array}$ & $\begin{array}{c}-961 G>A \\
\text { CCL22 }\end{array}$ & $\begin{array}{c}\text { CRC } \\
(n=245)\end{array}$ & $\begin{array}{l}\text { Controls } \\
(n=256)\end{array}$ \\
\hline 1 & $\mathrm{C} / \mathrm{C}$ & $\mathrm{G} / \mathrm{G}$ & $52.7(129)$ & $60.2(154)$ \\
\hline 2 & $\mathrm{C} / \mathrm{C}$ & $\mathrm{G} / \mathrm{A}$ & $30.6 \quad(75)$ & $23.4 \quad(60)$ \\
\hline 3 & $\mathrm{C} / \mathrm{C}$ & $\mathrm{A} / \mathrm{A}$ & $3.3 \quad(8)$ & $4.3 \quad(11)$ \\
\hline 4 & $\mathrm{C} / \mathrm{T}$ & $\mathrm{G} / \mathrm{A}$ & $11.0 \quad(27)$ & $8.2 \quad(21)$ \\
\hline 5 & $\mathrm{C} / \mathrm{T}$ & $\mathrm{G} / \mathrm{G}$ & $1.2 \quad(3)$ & $1.6 \quad(4)$ \\
\hline 6 & $\mathrm{C} / \mathrm{T}$ & $\mathrm{A} / \mathrm{A}$ & $1.2 \quad$ (3) & 1.6 \\
\hline 7 & $\mathrm{~T} / \mathrm{T}$ & $\mathrm{A} / \mathrm{A}$ & $0.0 \quad(0)$ & 0.7 \\
\hline
\end{tabular}

CRC patients versus controls, overall $\mathrm{p}=0.308$.

Table III. Genotype and allele numbers of the -431C>T CCL17 and -961G>A CCL22 gene polymorphisms regarding location and Dukes' stage in CRC patients.

\begin{tabular}{|c|c|c|c|c|c|c|c|c|c|c|}
\hline & \multicolumn{6}{|c|}{ Genotype } & \multicolumn{4}{|c|}{ Allele } \\
\hline & $\mathrm{C} / \mathrm{C}$ & $\mathrm{C} / \mathrm{T}$ & $\mathrm{T} / \mathrm{T}$ & $\mathrm{G} / \mathrm{G}$ & $\mathrm{G} / \mathrm{A}$ & $\mathrm{A} / \mathrm{A}$ & $\mathrm{C}$ & $\mathrm{T}$ & $\mathrm{G}$ & A \\
\hline $\begin{array}{l}\text { Colon } \\
(n=123)\end{array}$ & 107 & 16 & 0 & 75 & 42 & 6 & $230^{\mathrm{a}}$ & $16^{\mathrm{a}}$ & $192^{\mathrm{a}}$ & $54^{\mathrm{a}}$ \\
\hline $\begin{array}{l}\text { Rectum } \\
(\mathrm{n}=122)\end{array}$ & 105 & 17 & 0 & 57 & 60 & 5 & 227 & 17 & 174 & 70 \\
\hline $\begin{array}{l}\text { Dukes' stages A and B } \\
(n=149)\end{array}$ & 127 & 22 & 0 & 84 & 59 & 6 & $276^{\mathrm{b}}$ & $22^{\mathrm{b}}$ & $227^{\mathrm{b}}$ & $71^{b}$ \\
\hline $\begin{array}{l}\text { Dukes' stages } C \text { and D } \\
(n=96)\end{array}$ & 85 & 11 & 0 & 48 & 43 & 5 & 181 & 11 & 139 & 53 \\
\hline
\end{tabular}

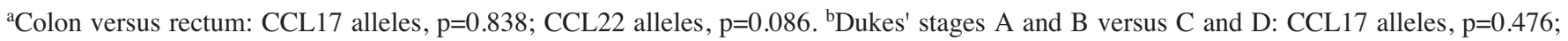
CCL22 alleles, $\mathrm{p}=0.348$.

Considerable attention has been focused on the identification of biomarkers that reflect tumour progression. However, little is known regarding the protein levels of CCL17 and CCL22 in CRC patients. In the current study, we determined the levels of CCL17 and CCL22 protein in plasma, cancer tissue and paired normal tissue from CRC patients. A significantly higher expression of CCL22 in tumour tissue with a 2.3-fold up-regulation (tumour vs. normal tissue) was noted. No significant difference regarding CCL17 protein expression was observed between cancer and normal paired tissue, and the levels of CCL22 and CCL17 protein in analysed tissue samples from CRC patients were not associated with plasma levels or clinical characteristics.

Moreover, to identify the cellular source and localization of CCL17 and CCL22 protein, we used immunohistochemistry and found immunoreactivity in the epithelial compartment of cancer tissue and in epithelial cells at the resection border that reflects normal tissue, and also in some stromal cells such as lymphocytes, macrophages and fibroblasts.
Our results may confirm the finding of Musha et al (26) that, in a limited number of cases $(n=5)$, a higher gene expression of CCL22 but not of CCL17 was exhibited in colon cancer compared to non-neoplastic colon. Our study showed that neither CCL17 nor CCL22 seem to be useful clinical markers regarding the relationship between plasma or tissue levels and clinical characteristics. However, in a forthcoming study it would be informative to investigate the influence of the tissue levels of CCL22 protein on the 5-year survival rate of CRC patients. Notably, we demonstrated that the protein levels of CCL17 and CCL22, respectively, in cancerous tissue and in normal tissue, were significantly correlated. One may speculate that the two chemokines are regulated to maintain a local immunological balance in colorectal tissue, but in cancerous tissue a different pathway promotes the protein expression of CCL22. However, the biological significance of the difference remains unknown and the underlying mechanisms unclear.

Both the $-431 \mathrm{C}>\mathrm{T}$ and $-961 \mathrm{G}>\mathrm{A}$ SNP are located in the promoter region of the CCL17 and CCL22 gene, respectively 
(27), and the CCL17 gene variant $-431 \mathrm{C}>\mathrm{T}$ was previously described as having a functional consequence on serum levels $(28,29)$. We therefore investigated the prevalence of these gene polymorphisms in CRC patients and control subjects. This, to our knowledge, has not been performed before. Our data showed that genotype distribution and allelic frequencies were not significantly associated with CRC compared to control subjects. However, a trend $(\mathrm{p}=0.055)$ towards a difference in the genotype distribution of the $-961 \mathrm{G}>\mathrm{A}$ SNP of CCL22 was found. We were also unable to detect any association between the genotype and plasma or tissue concentration of CCL17 and CCL22 proteins in CRC patients.

The role of chemokines in tumour biology is complex. They play an important role in local immunoregulation by the attraction and guidance of leukocytes, leading to antitumour immunity or contributing to the growth and spread of the tumour (1-9). T cell infiltration has been shown to be associated with a favourable prognosis in CRC $(10,11)$. Berin et al reported that CCL17 and CCL22 expression in intestinal cells appears to differ between different mucosal sites and that CCL22, but not CCL17, is produced by intestinal epithelial cells in response to pro-inflammatory cytokines (25). This diversity may explain their divergent functions, and may reflect our finding of the differential expression of CCL17 and CCL22 in CRC. Since CCL17 and CCL22 signal through CCR4, they can act as chemoattractants for Th2 CD4+ T-cell-mediated immunity (19-21). CCR4 is also expressed on Tregs, which play an important role in maintaining immune balance and have been detected in the peripheral blood of humans $(22,23)$. Tregs are known to be a potent inhibitor of the antitumour immune response (32). Recently, a study on CRC patients found that the amount of Tregs was significantly higher in CRC than in the normal colon (33). Thus a functional consequence of our finding, that CCL22 protein expression is increased in CRC, could be a higher infiltration of Tregs implicating a tumour immune evasion strategy.

To the best of our knowledge, this is the first report on the influence of CCL17 and CCL22 gene variants and their protein expression in a large scale study regarding human CRC. The results of this study, however, demonstrated that these gene variants are not associated with susceptibility to CRC. To ascertain whether the tissue expression of CCL17 and CCL22 exerts an influence on the pathogenesis of $\mathrm{CRC}$, a forthcoming study on the 5-year survival rate of CRC patients will be conducted.

\section{Acknowledgements}

This work was supported by grants from Futurum, The Academy of Healthcare, County Council of Jönköping, Sweden and the University College of Health Sciences, Jönköping. We thank Marita Skarstedt (Ryhov County Hospital, Jönköping) for excellent technical support. We also express our gratitude to Dr Reine Rosander for valuable statistical consultation.

\section{References}

1. Moser B, Wolf M, Walz A and Loetscher P: Chemokines: multiple levels of leukocyte migration control. Trends Immunol 25: 75-84, 2004.
2. Dwinell MB, Johanesen PA and Smith JM: Immunobiology of epithelial chemokines in the intestinal mucosa. Surgery 133: 601-607, 2003.

3. Luster AD: Chemokines regulate lymphocyte homing to the intestinal mucosa. Gastroenterology 120: 291-294, 2001.

4. Arya M, Patel HR and Williamson M: Chemokines: key players in cancer. Curr Med Res Opin 19: 557-564, 2003.

5. Balkwill $\mathrm{F}$ and Mantovani A: Inflammation and cancer: back to Virchow? Lancet 357: 539-545, 2001.

6. Coussens LM and Werb Z: Inflammation and cancer. Nature 420: 860-867, 2002

7. Balkwill F: Chemokine biology in cancer. Semin Immunol 15: 49-55, 2003.

8. Strieter RM, Burdick MD, Mestas J, Gomperts BN, Keane MP and Belperio JA: Cancer CXC chemokine networks and tumour angiogenesis. Eur J Cancer 42: 768-778, 2006.

9. Zlotnik A: Chemokines in neoplastic progression. Semin Cancer Biol 14: 181-185, 2004.

10. Ohta M, Tanaka F, Yamaguchi H, Sadanaga N, Inoue H and Mori M: The high expression of Fractalkine results in a better prognosis for colorectal cancer patients. Int J Oncol 26: 41-47, 2005.

11. Ropponen KM, Eskelinen MJ, Lipponen PK, Alhava E and Kosma VM: Prognostic value of tumour-infiltrating lymphocytes (TILs) in colorectal cancer. J Pathol 182: 318-324, 1997.

12. Kanagawa N, Niwa M, Hatanaka Y, Tani Y, Nakagawa S, Fujita T, Yamamoto A and Okada N: CC-chemokine ligand 17 gene therapy induces tumor regression through augmentation of tumor-infiltrating immune cells in a murine model of preexisting CT26 colon carcinoma. Int J Cancer 121: 2013-2022, 2007.

13. Imai T, Yoshida T, Baba M, Nishimura M, Kakizaki M and Yoshie O: Molecular cloning of a novel T cell-directed CC chemokine expressed in thymus by signal sequence trap using Epstein-Barr virus vector. J Biol Chem 271: 21514-21521, 1996.

14. Sallusto F, Schaerli P, Loetscher P, Schaniel C, Lenig D, Mackay CR, Qin S and Lanzavecchia A: Rapid and coordinated switch in chemokine receptor expression during dendritic cell maturation. Eur J Immunol 28: 2760-2769, 1998.

15. Campell JJ, Haraldsen G, Pan J, Rottman J, Qin S, Ponath P, Andrew DP, Warnke R, Ruffing N, Kassam N, Wu L and Butcher EC: The chemokine receptor CCR4 in vascular recognition by cutaneous but not intestinal memory $\mathrm{T}$ cells. Nature 400: 776-780, 1999.

16. Judge F, Alizadeh M, Boissier C, Chantry D, Siproudhis L, Corbinais S, Quelvennec E, Dyard F, Campion JP, Gosselin M, Bretagne JF, Semana G and Heresbach D: Quantitation of chemokine (MDC, TARC) expression in mucosa from Crohn's disease and ulcerative colitis. Eur Cytokine Netw 12: 468-477, 2001.

17. Yu B, Koga T, Urabe K, Moroi Y, Maeda S, Yanagihara Y and Furue M: Differential regulation of thymus- and activationregulated chemokine induced by IL-4, IL-13, TNF- $\alpha$ and IFN- $\gamma$ in human keratinocyte and fibroblast. J Dermatol Sci 30: 29-36, 2002.

18. Yoshie O, Imai $\mathrm{T}$ and Nomiyama $\mathrm{H}$ : Chemokines in immunity. Adv Immunol 78: 57-110, 2001

19. Imai T, Nagira M, Takagi S, Kakizaki M, Nishimura M, Wang J, Gray PW, Matsushima K and Yoshie O: Selective recruitment of CCR4-bearing Th2 cells toward antigen-presenting cells by the CC chemokines thymus and activation-regulated chemokine and macrophage-derived chemokine. Int Immunol 11: 81-88, 1999.

20. D'Ambrosio D, Iellem A, Bonecchi R, Mazzeo D, Sozzani S, Mantovani A and Sinigaglia F: Selective up-regulation of chemokine receptors CCR 4 and CCR 8 upon activation of polarized human type 2 Th cells. J Immunol 161: 5111-5115, 1998.

21. Sallusto F, Lenig D, Mackay CR and Lanzavecchia A: Flexible programs of chemokine receptor expression on human polarized T helper 1 and 2 lymphocytes. J Exp Med 187: 875-883, 1998.

22. Jonuleit H, Schmitt E, Stassen M, Tuettenberg A, Knop J and Enk AH: Identification and functional characterization of human CD4(+)CD25(+) T cells with regulatory properties isolated from peripherial blood. J Exp Med 193: 1285-1294, 2001.

23. Ng WF, Duggan PJ, Ponchel F, Matarese G, Lombardi G, Edwards AD, Isaacs JD and Lechler RI: Human CD4(+) CD25(+) cells: a naturally occurring population of regulatory $\mathrm{T}$ cells. Blood 98: 2736-2744, 2001. 
24. Godiska R, Chantry D, Raport CJ, Sozzani S, Allavena P, Leviten D, Mantovani A and Gray PW: Human macrophagederived chemokine (MDC) a novel chemoattractant for monocytes, monocyte-derived dendritic cells and natural cells. J Exp Med 185: 1595-1604, 1997.

25. Berin CM, Dwinell MB, Eckman L and Kagnoff MF: Production of MDC/CCL22 by human intestinal epithelial cells. Am J Physiol Gastrointest Liver Physiol 280: G1217-G1226, 2001.

26. Musha H, Ohtani H, Mizoi T, Kinouchi M, Nakayama T, Shiiba K, Miyagawa, Nagura H, Yoshie O and Sasaki I: Selective infiltration of $\mathrm{CCR}^{+} \mathrm{CXCR}^{+} \mathrm{T}$ lymphocytes in human colorectal carcinoma. Int J Cancer 116: 949-956, 2005.

27. Fisher SA, Moody A, Mirza MM, Cuthbert AP, Hampe J, Macpherson A, Sanderson J, Forbes A, Mansfield J, Schreiber S, Lewis CM and Mathew CG: Genetic variation at the chromosome 16 chemokine gene cluster: development of a strategy for association studies in complex disease. Ann Hum Genet 67: 377-390, 2003.

28. Sekiya T, Tsunami Y, Miyamasu M, Ohta K, Morita A, Saeki H, Matsushima K, Yoshie O, Tsuchiya N, Yamaguchi M, Yamamoto K and Hirai K: Variations in the human Th2-specific chemokine TARC gene. Immunogenetics 54: 742-745, 2003.
29. Tsunemi Y, Komine M, Sekiya T, Saeki H, Nakamura K, Kakinuma T, Kagami S, Fujita H, Asano N, Tanida Y, Wakugawa M, Torii $\mathrm{H}$ and Tamaki $\mathrm{K}$ : The $-431 \mathrm{C}>\mathrm{T}$ polymorphism of the thymus and activation-regulated chemokine increases the promoter activity but is not associated with susceptibility to atopic dermatitis in Japanese patients. Exp Dermatol 13: 715-719, 2004

30. Hashimoto S, Nakamura K, Oyama N, Kaneko F, Tsunemi Y, Saeki $\mathrm{H}$ and Tamaki K: Macrophage-derived chemokine (MDC)/CCL22 produced by monocyte derived cells reflects the disease activity in patients with atopic dermatitis. J Dermatol Sci 44: 93-99, 2006.

31. Ferenczi K, Fuhlbrigge RC, Pinkus JL, Pinkus GS and Kupper TS: Increased CCR4 expression in cutaneous T cell lymphoma. J Invest Dermatol 119: 1404-1410, 2002.

32. Shimizu J, Yamazaki S and Sakaguchi S: Induction of tumor immunity by removing $\mathrm{CD} 25^{+} \mathrm{CD} 4^{+} \mathrm{T}$ cells: a common basis between tumor immunity and autoimmunity. J Immunol 163: 5211-5218, 1999.

33. Loddenkemper C, Schernus M, Noutsias M, Stein H, Thiel E and Nagorsen D: In situ analysis of FOXP $3^{+}$regulatory $\mathrm{T}$ cells in human colorectal cancer. J Transl Med 4: 52, 2006. 